\title{
A 900-year New England temperature reconstruction from in situ seasonally produced branched glycerol dialkyl glycerol tetraethers (brGDGTs)
}

\author{
Daniel R. Miller ${ }^{1,2}$, M. Helen Habicht ${ }^{2}$, Benjamin A. Keisling ${ }^{2}$, Isla S. Castañeda ${ }^{2}$, and Raymond S. Bradley ${ }^{1,2}$ \\ ${ }^{1}$ Northeast Climate Adaptation Science Center, University of Massachusetts Amherst, Amherst, MA 01003, USA \\ ${ }^{2}$ Climate System Research Center, Department of Geosciences, University of Massachusetts Amherst, \\ Amherst, MA 01003, USA
}

Correspondence: Daniel R. Miller (dmiller@geo.umass.edu)

Received: 27 March 2018 - Discussion started: 3 April 2018

Revised: 12 September 2018 - Accepted: 23 October 2018 - Published: 7 November 2018

\begin{abstract}
Paleotemperature reconstructions are essential for distinguishing anthropogenic climate change from natural variability. An emerging method in paleolimnology is the use of branched glycerol dialkyl glycerol tetraethers (brGDGTs) in sediments to reconstruct temperature, but their application is hindered by a limited understanding of their sources, seasonal production, and transport. Here, we report seasonally resolved measurements of brGDGT production in the water column, in catchment soils, and in a sediment core from Basin Pond, a small, deep inland lake in Maine, USA. We find similar brGDGT distributions in both water column and lake sediment samples but the catchment soils have distinct brGDGT distributions suggesting that (1) brGDGTs are produced within the lake and (2) this in situ production dominates the down-core sedimentary signal. Seasonally, depthresolved measurements indicate that most brGDGT production occurs in late fall, and at intermediate depths (18-30 m) in the water column. We utilize these observations to help interpret a Basin Pond brGDGT-based temperature reconstruction spanning the past 900 years. This record exhibits trends similar to a pollen record from the same site and also to regional and global syntheses of terrestrial temperatures over the last millennium. However, the Basin Pond temperature record shows higher-frequency variability than has previously been captured by such an archive in the northeastern United States, potentially attributed to the North Atlantic Oscillation and volcanic or solar activity. This first brGDGTbased multi-centennial paleoreconstruction from this region contributes to our understanding of the production and fate of brGDGTs in lacustrine systems.
\end{abstract}

\section{Introduction}

Anthropogenic climate change is one of the most complex and challenging issues facing the world today and its impacts will likely be exacerbated in heavily populated areas, such as the northeastern United States (NE US) (Fig. 1), a region comprised of communities that have been historically susceptible to climate change (Horton et al., 2014). Here, over the past 120 years average temperatures have increased by $\sim 1{ }^{\circ} \mathrm{C}$, precipitation has increased by $10 \%$, and sea levels have risen by $\sim 40 \mathrm{~cm}$ (Kunkel et al., 2013; NOAA, 2014). While historical records document the temperature increase in the past century, they are not long enough to capture the underlying variability in the pre-anthropogenic period. Therefore, high-resolution paleotemperature records, such as those developed from lacustrine sedimentary sequences, are needed to investigate how current climate change compares to long-term natural variability. A regional synthesis of NE US late Holocene climate variability by Marlon et al. (2017) reviews temperature reconstructions from terrestrial sediment records using methods such as pollen (Gajewski, 1987; Webb et al., 2003; Oswald et al., 2007), testate amoeba (Clifford and Booth, 2013), and leaf wax hydrogen isotopic ratios (Huang et al., 2004, Shuman et al., 2006; Gao et al., 2017). However, these climate proxies may also reflect changes in parameters other than temperature (i.e., precipitation, humidity, evapotranspiration, and vegetation) (Gajewski, 1988; Hou et al., 2008; Marlon et al., 2017). Therefore, additional quantitative paleotemperature records are needed 


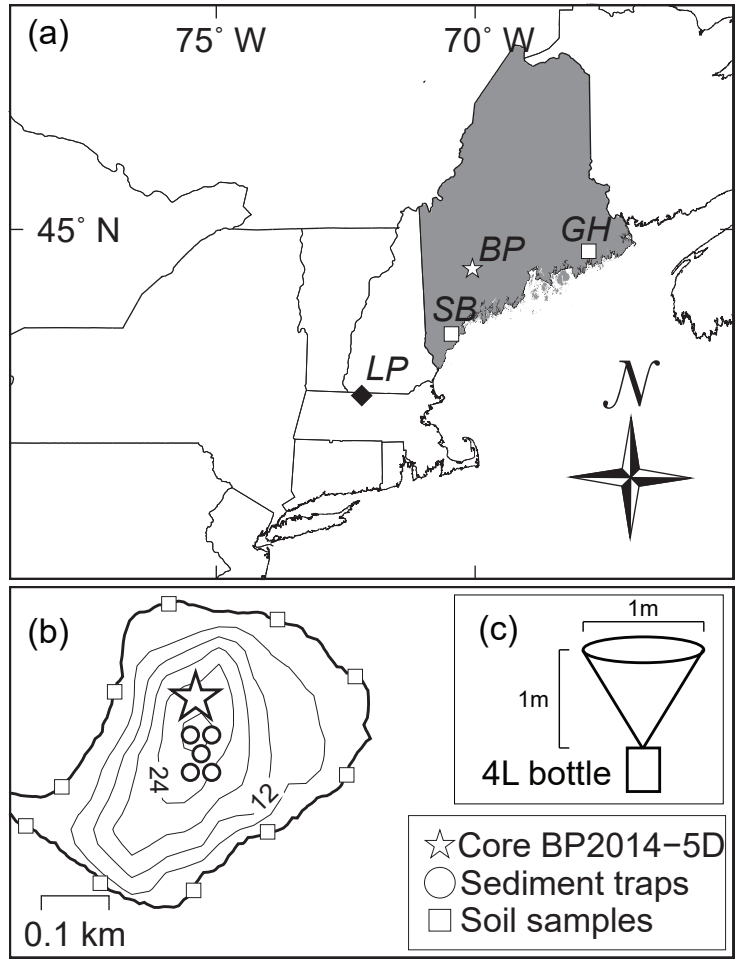

Figure 1. Map of Basin Pond. (a) The location of Basin Pond (BP) (white star) in Maine, USA. Locations of three other sites are labeled: Little Pond (LP; Gao et al., 2017), Great Heath Lake (GH; Nichols and Huang, 2012; Clifford and Booth, 2013), and Saco Bog (SB; Clifford and Booth, 2013). (b) Bathymetric profile (6 m contours) of Basin Pond with position of floating sediment traps (circles), surface soil samples (squares), and core BD-2014-5D used for the down-core temperature reconstruction in this study (star). The pond has an area of approximately $0.14 \mathrm{~km}^{2}$. (c) Schematic of sediment traps utilized in this study.

to accurately assess past temperature variability in the $\mathrm{NE}$ US (Marlon et al., 2017).

Branched glycerol dialkyl glycerol tetraethers (brGDGTs), found globally in lakes, soils, rivers, and peats, provide an independent terrestrial paleothermometer well suited to this task (e.g., Weijers et al., 2007; Peterse et al., 2012; De Jonge et al., 2013, 2015; Buckles et al., 2014). BrGDGTs are comprised of two ether-linked dialkyl chains containing zero to two methyl branches (prefixes I, II, and III) and zero to two cyclopentane moieties (suffixes a, b, and c) (Sinninghe Damsté et al., 2000). Although the source organisms are unknown, these compounds are thought to be produced in part by Acidobacteria (e.g., Sinninghe Damsté et al., 2011, 2018). Noting a strong correlation between mean annual air temperature (MAAT) and the degree of methylation of brGDGTs in global soils, Weijers et al. (2007) proposed that sedimentary brGDGTs could be used as a proxy for past soil temperature, which in many cases is similar to MAAT. This motivated the development and later refinement of two indices, based on the degree of methylation and cyclization of brGDGTs (MBT and CBT), which were correlated to temperature and $\mathrm{pH}$, respectively (e.g., Weijers et al., 2007; Peterse et al., 2012; De Jonge et al., 2014a).

More recently, improved chromatographic separation techniques for brGDGTs have been developed and indicated the presence of 5- and 6-methyl brGDGT isomers (De Jonge et al., 2013; De Jonge et al., 2014; Hopmans et al., 2016). The 6-methyl isomers may be abundant in environmental samples (De Jonge et al., 2014b), and failure to account for the presence of these compounds can have a significant influence on reconstructed temperatures (De Jonge et al., 2013, 2014a). Importantly, De Jonge et al. (2014a) demonstrated that soil $\mathrm{pH}$ (CBT) does not have an influence on the degree of methylation (MBT) and that earlier observations suggesting an influence of $\mathrm{pH}$ on methylation (Weijers et al., 2007) were the result of incomplete isomer separation. A new index based on the 5-methyl brGDGTs ( $\mathrm{MBT}_{5 \mathrm{ME}}^{\prime}$ ) was developed and calibrated to temperature using a global soils dataset (De Jonge et al., 2014). $\mathrm{MBT}_{5 \mathrm{ME}}^{\prime}$ and 5-methyl fractional abundances have recently been calibrated for temperature reconstruction in lakes from East Africa (Russell et al., 2018) and China (Dang et al., 2018).

Initially, brGDGTs were presumed to be exclusively produced in soils and subsequently washed into lakes or marine environments via erosion by rivers and streams (Hopmans et al., 2004). Further research demonstrated these compounds are also produced in situ in lakes and rivers (e.g., Tierney and Russell, 2009; Bechtel et al., 2010; Tierney et al., 2010; Zhu et al., 2011; Loomis et al., 2012; Schoon et al., 2013; Zell et al., 2013). Although some studies suggest that distinct brGDGTs are produced within the water column of lakes (Colcord et al., 2015; Weber et al., 2015) and show that their production is seasonally biased (e.g., Buckles et al., 2014; Loomis et al., 2014), relatively limited work has been carried out to understand their in situ production and its consequences for the sedimentary brGDGT record (Zhang et al., 2016). Knowledge of brGDGT production and seasonality is important for appropriately calibrating and interpreting down-core records, yet few studies have combined modern observations of brGDGT distributions in the environment with a paleoclimate reconstruction for a temperate lake system.

Here we examine brGDGT abundances and distributions in catchment soil samples and at varying depths in the water column throughout the year at an inland lake in the NE US (Fig. 1). We collected samples from 2014 to 2015 to assess the seasonality and location of brGDGT production in and around Basin Pond, ME. We then use our observations to help interpret a 900-year-long relative temperature record, providing the first decadally resolved brGDGT-derived lacustrine paleoclimate reconstruction for this region. 


\section{Site information and field sampling}

\subsection{Study site}

Basin Pond, located in Fayette, $\mathrm{ME}\left(44^{\circ} 28^{\prime} \mathrm{N}, 70^{\circ} 03^{\prime} \mathrm{W}\right.$, elevation $124 \mathrm{~m}$ above sea level), is a small, deep lake with an area of $0.14 \mathrm{~km}^{2}$ and a maximum depth of $32.6 \mathrm{~m}$ (Fig. 1). Basin Pond is fed from groundwater and precipitation, with one small dammed outlet stream running westward into the adjacent David Pond (Frost, 2005). Most of the $0.53 \mathrm{~km}^{2}$ catchment area is dominated by a well-developed deciduous hardwood and evergreen forest, with only one residential building. MAAT at Basin Pond is $\sim 5.9^{\circ} \mathrm{C}$ and average annual precipitation is $\sim 1150 \mathrm{~mm}$ (NOAA, 2014).

Basin Pond contains a unique sedimentary sequence comprised of annual laminations (varves) due to permanent water column stratification (Wetzel, 1983; Frost, 2005) resulting from a persistent thermocline. This stratification causes permanent bottom water anoxia, which enhances the preservation of annual laminations throughout the record (O'Sullivan, 1983). The Basin Pond varves are biogenic, with couplets comprised of a lighter diatom-rich summer layer and a darker humic winter layer (Frost, 2005).

The extent of anthropogenic impacts on Basin Pond and its catchment area have varied over the study interval. Although people were certainly present in Maine for the past 900 years, European-settler land clearance did not begin until the mid1700s (Foster and Aber, 2004). It is uncertain whether the Basin Pond catchment was affected by this process. Due to its relatively remote location in New England, Maine experienced substantially less deforestation compared with the other NE US states (Foster and Aber, 2004). However, polycyclic aromatic hydrocarbons (PAHs) reflecting regional anthropogenic activity indicate that industrialization is notable in the Basin Pond sedimentary record (Miller et al., 2017). Furthermore, the lake's natural chemistry was disrupted in the 1950s, when Basin Pond was treated with a chemical piscicide, rotenone (United States Geological Survey, 1996). Today, the lake is lightly used for recreation by members of the Basin, David, and Tilton Ponds Association.

\subsection{Sediment coring}

Sediment coring was performed from ice in March 2014, in the deepest part of the lake at $32 \mathrm{~m}\left(44^{\circ} 27^{\prime} 27^{\prime \prime} \mathrm{N}\right.$, $70^{\circ} 03^{\prime} 09^{\prime \prime} \mathrm{W}$ ), using a Uwitec gravity coring system. Core BP2014-3D $(52 \mathrm{~cm})$ captured an undisturbed sedimentwater interface and was subsampled in the field at $0.5 \mathrm{~cm}$ resolution for radioisotopic dating. Core BP2014-5D $(174 \mathrm{~cm})$ was immediately capped upon retrieval. Cores were split and photographed, and nondestructive down-core logging was performed using an Itrax XRF core scanner with a molybdenum tube at $100 \mu \mathrm{m}$ resolution in the Department of Geosciences at University of Massachusetts Amherst. Cores were kept refrigerated for 1 month prior to subsampling. Subsamples were stored frozen in Whirl-Pak bags until extraction.

\subsection{Sediment trap construction, deployment, and retrieval}

Sediment traps were designed and constructed at University of Massachusetts Amherst. Sediment trap collection cones were made of high-density polyethylene (HDPE) with a diameter of $\sim 1 \mathrm{~m}$ (Fig. 1) and attached to $4 \mathrm{~L}$ bottles for settling particulate matter (SPM) collection (Fig. 1). Note that our definition of SPM includes both material suspended in the water column and settling into the traps. Five sediment traps were deployed on 27 May 2014 at 6, 12, 18, 24, and $30 \mathrm{~m}$ in depth. SPM was collected from all traps on 2 July, 16 August, and 14 September 2014 and 5 June 2015. Each trap continuously accumulated SPM from deployment until collection and therefore each sample represents material collected over 36, 40, 28, and 264 days. The length of the last sampling period of 264 days was due to ice cover at the lake; sediment trap recovery was not possible until ice-out. SPM labels in Figs. 2, 3, and 5 and throughout the discussion are referred to by the month that was the midpoint of each collection period. Thus, the four sampling periods listed above are referred to as June, July, September, and January SPM. Catchment soil samples were also collected around the perimeter of the lake at the time of initial trap deployment. All soil and water SPM samples were kept frozen until analysis.

\section{Methods}

\subsection{Sedimentary age model}

Subsamples for past climate reconstruction were taken every $0.5 \mathrm{~cm}$ from the uppermost $68 \mathrm{~cm}$ of core BP2014-5D. The age model for Basin Pond is based on ${ }^{210} \mathrm{~Pb}$, varve counts, and five ${ }^{14} \mathrm{C}$ dates and was previously published by Miller et al. (2017). The sediment examined here ranges in age from modern to $\sim 1100 \mathrm{BP}$, with a sampling resolution of 4 to 13 years (median: 7) (Miller et al., 2017).

\subsection{Laboratory methods}

Overall, 10 catchment soil samples, 19 SPM sediment trap samples, and 136 sediment core samples were analyzed. Soil and lake sediment samples were freeze-dried and homogenized prior to extraction. For SPM samples, water from each collection bottle was filtered through a $47 \mathrm{~mm}, 0.3 \mu \mathrm{m}$ combusted Sterlitech glass fiber membrane filter and dried prior to extraction. For most samples, a total lipid extract (TLE) was obtained using a Dionex accelerated solvent extractor (ASE 200) with a mixture of dichloromethane (DCM) / methanol (MeOH) $(9: 1, v / v)$. For four SPM samples, plastic filters were washed and sonicated with water 
of high-performance liquid chromatograph (HPLC) grade, which was subsequently extracted with DCM three times. TLEs from SPM and catchment soil samples were separated into apolar $(9: 1 \mathrm{DCM} /$ hexane $v / v)$ and polar $(1: 1$ $\mathrm{DCM} / \mathrm{MeOH} v / v$ ) fractions, while the lake sediment samples were separated into apolar, ketone $(1: 1$ hexane / DCM $v / v$ ), and polar fractions using alumina oxide column chromatography. For all samples, one-half of each polar fraction was filtered through $0.45 \mu \mathrm{m}$ PTFE syringe filters using 99: 1 hexane / isopropanol $(v / v)$. A total of $0.1 \mu \mathrm{g}$ of $\mathrm{C}_{46}$ GDGT internal standard was added to each polar fraction prior to analysis. The other half of each polar fraction was derivatized using bis (trimethylsiyl) trifluoroacetamide (BSTFA), and algal biomarkers were identified with a Hewlett-Packard 6890 Series gas chromatograph coupled to an Agilent 5973 mass spectrometer (GC-MS) using a Restek Rtx-5MS $(60 \mathrm{~m} \times 250 \mu \mathrm{m} \times 0.25 \mu \mathrm{m})$ column. Algal biomarkers, (iso)loliolide, $\mathrm{C}_{30}$ 1,13n-alkyl diol, dinosterol / stanol, and $\beta$-sitosterol / stanol, were quantified with an Agilent 7890A dual gas chromatograph-flame ionization detector (GC-FID) equipped with two Agilent 7693 autosamplers and two identical columns (Agilent 19091J-416: $325^{\circ} \mathrm{C}: 60 \mathrm{~m} \times 320 \mu \mathrm{m} \times 0.25 \mu \mathrm{m}, \mathrm{HP}-55 \%$ phenyl methyl siloxan). For both the GC-MS and GC-FID, helium was used as the carrier gas. The ovens began at a temperature of $70^{\circ} \mathrm{C}$, increased at $10^{\circ} \mathrm{C} \mathrm{min}^{-1}$ to $130^{\circ} \mathrm{C}$, increased again at $4{ }^{\circ} \mathrm{C} \min ^{-1}$ to $320^{\circ} \mathrm{C}$, and then held the temperature for $10 \mathrm{~min}$. The GCs were run in splitless mode. Compounds were quantified using an external calibration curve for which squalane was injected at multiple concentrations ranging from 2 to $100 \mathrm{ng} \mu \mathrm{L}^{-1} ; r^{2}$ values for linearity tests were $>0.99$.

\section{3 brGDGT analysis}

Polar fractions were analyzed on an Agilent 1260 HPLC coupled to an Agilent 6120 Quadrupole mass selective detector (MSD). Compound separation was achieved using the method of Hopmans et al. (2016). The technique uses two Waters BEH HILIC columns in series $(150 \mathrm{~mm} \times 2.1 \mathrm{~mm}$, $1.7 \mu \mathrm{m})$ and isocratically elutes brGDGTs using a mixture of hexane (solvent $\mathrm{A}$ ) and hexane: isopropanol $(9: 1, v: v$, solvent B) in the following sequence: $18 \% \mathrm{~B}(25 \mathrm{~min})$, linear increase to $35 \% \mathrm{~B}$ (25 min), linear increase to $100 \% \mathrm{~B}$ (30 min). Mass scanning was performed in selected ion monitoring (SIM) mode. The brGDGTs were quantified with respect to the $\mathrm{C}_{46}$ standard, assuming equal ionization efficiency for all compounds. For calculation of $\mathrm{MBT}_{5 \mathrm{ME}}^{\prime}$, $\mathrm{CBT}_{5 \mathrm{ME}}^{\prime}$, and the isomer ratio (IR), the following equations

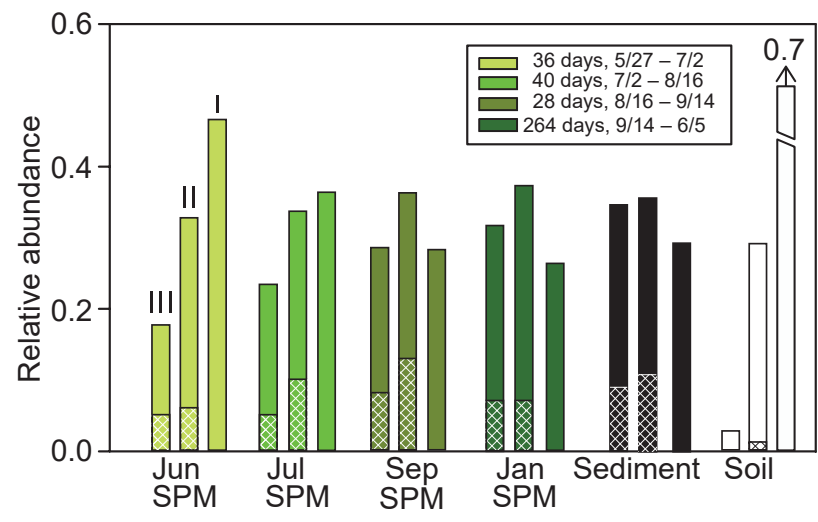

Figure 2. Temporal variation in the relative abundance of group I, II, and III brGDGTs in SPM (green shaded bars), sediment (black bars), and catchment soil samples (white bars). Sediment and soil samples were collected in spring of 2014. Green shaded bars for SPM samples reflect averages for each date samples were collected, measured in July 2014 (lightest green), August 2014, September 2014, and June 2015 (darkest green). For each category, brGDGT groups III, II, and I are shown in that order (left to right). Lines in each bar represent the relative abundance of 5and 6-methyl brGDGTs, with cross hatching representing 6-methyl abundances.

were used from De Jonge et al. (2014a, b).

$$
\begin{aligned}
& \mathrm{MBT}^{\prime}{ }_{5 \mathrm{ME}}=\frac{\mathrm{Ia}+\mathrm{Ib}+\mathrm{Ic}}{\mathrm{IIIa}+\mathrm{IIa}+\mathrm{IIb}+\mathrm{IIc}+\mathrm{Ia}+\mathrm{Ib}+\mathrm{Ic}} \\
& \mathrm{CBT}^{\prime}{ }_{5 \mathrm{ME}}=-\log \left(\frac{\mathrm{Ib}+\mathrm{IIb}}{\mathrm{Ia}+\mathrm{IIa}}\right) \\
& \mathrm{IR}= \\
& \frac{\mathrm{IIa}^{\prime}+\mathrm{IIb}^{\prime}+\mathrm{IIc}^{\prime}+\mathrm{III}^{\prime}+\mathrm{IIIb}^{\prime}+\mathrm{IIIc}^{\prime}}{\mathrm{IIa}+\mathrm{IIa}^{\prime}+\mathrm{IIb}_{\mathrm{IIb}}+\mathrm{IIc}_{\mathrm{II}}+\mathrm{IIII}^{\prime}+\mathrm{IIIa}^{\prime}+\mathrm{IIIb}+\mathrm{IIIb}^{\prime}+\mathrm{IIIc}+\mathrm{IIIc}^{\prime}}
\end{aligned}
$$

For samples measured in duplicate $(n=32)$, the maximum $\mathrm{MBT}_{5 \mathrm{ME}}^{\prime}$ difference was $<0.01$, while the maximum $\mathrm{CBT}_{5 \mathrm{ME}}^{\prime}$ was 0.01 ; thus analytical error associated with proxy application is insignificant.

\subsection{Time series analysis}

To analyze the variance in the data presented here, we used the astrochron R package (Meyers, 2012). Preprocessing of the data was kept to a minimum to avoid introducing spurious signals. The down-core brGDGT reconstruction was reinterpolated to 7-year resolution (equivalent to median resolution of the raw data; see results) prior to spectral analysis. The published PAGES2k datasets were analyzed with their published chronologies, which is 1-year resolution for most regions and 10 years for the North American tree-ring-based reconstruction (PAGES2k, 2013). Each of these reconstructions was smoothed to 7-year averages for easier comparison to our record. 


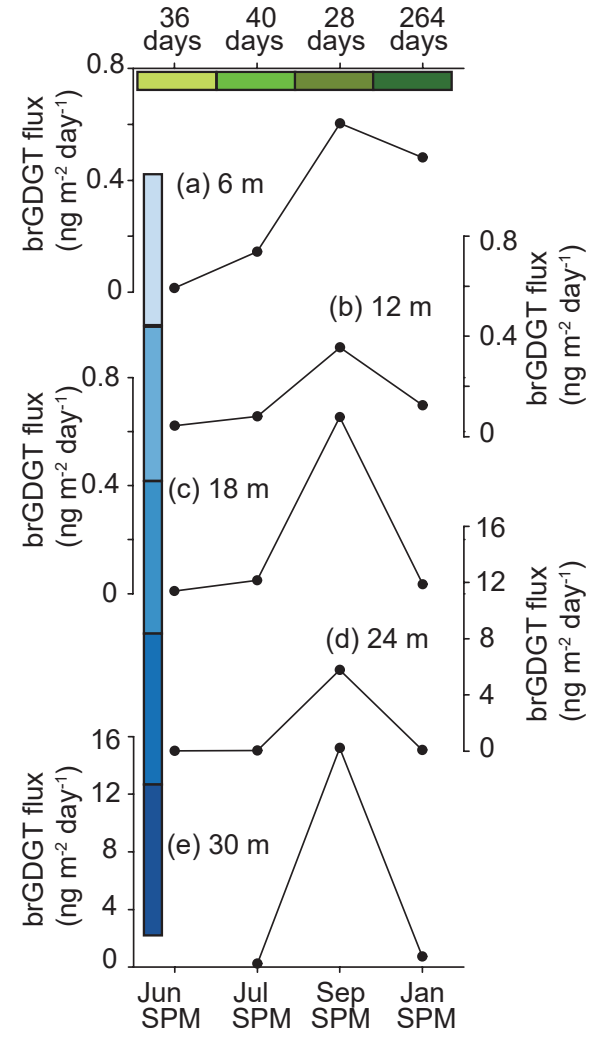

Figure 3. Time series of brGDGT fluxes for each of the sediment traps in Basin Pond. The brGDGT fluxes at 6 (a), 12 (b), 18 (c), 24 (d), and $30 \mathrm{~m}$ (e) are shown. There are no data for the trap (e) in July 2014. Note the change of scale for (d) and (e), indicating fluxes an order of magnitude higher for the lowermost traps. Green bars correspond to the time periods in Fig. 2. Blue bars correspond to the depth ranges in Fig. 5.

\section{Results}

BrGDGTs were present in all soil, SPM, and sediment core samples analyzed. In contrast, isoprenoid GDGTs, on which the $\mathrm{TEX}_{86}$ temperature proxy is based (Schouten et al., 2002), were undetectable in the majority of samples or present in very low abundances compared to the brGDGTs. Therefore, TEX $_{86}$ could not be utilized as a temperature proxy at Basin Pond.

\subsection{Catchment soils}

BrGDGTs Ia and IIa dominated distributions in the catchment soil samples, with relative abundances of $65 \% \pm 13 \%$ and $28 \% \pm 7 \%$, respectively (Fig. 2). The next largest relative abundances were IIIa and $\mathrm{Ib}$, comprising $3 \% \pm 6 \%$ and $3 \% \pm$ $1 \%$, respectively (Fig. 2). Total brGDGT concentrations in soils ranged from 1.5 to 7.3 (median $=2.2) \mu \mathrm{g} \mathrm{sed}^{-1}$.

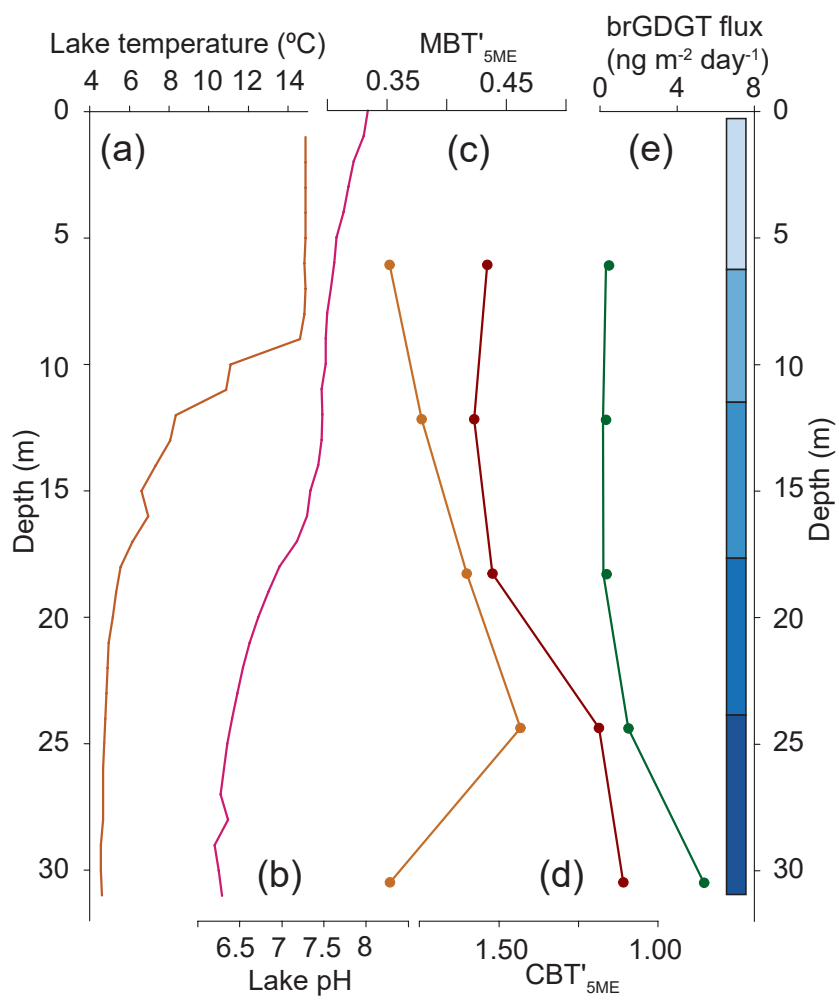

Figure 4. Hydrolab-measured temperature and $\mathrm{pH}$ profiles for Basin Pond compared with flux-weighted average brGDGT-based reconstructions. (a) Fall lake temperature profile, showing the mixed layer extending to $\sim 9 \mathrm{~m}$ in water depth, followed by the thermocline (9-15 m) and a cold deep layer (15-32 m). (b) Fall pH profile. The $\mathrm{pH}$ ranges from $\sim 7.5$ at the surface to $\sim 6.2$ at depth (c) Flux-weighted average MBT values measured at sediment traps. (d) Flux-weighted average CBT values measured at sediment traps. (e) The brGDGT fluxes measured at sediment traps. Blue bars correspond to the depth ranges in in Fig. 5.

\subsection{SPM}

BrGDGTs Ia, IIa, and IIIa dominated distributions in the SPM samples, with relative abundances of $28 \% \pm 8 \%$, $37 \% \pm 7 \%$, and $30 \% \pm 8 \%$, respectively (Fig. 2). The next largest relative abundances were $\mathrm{Ib}$ and $\mathrm{IIb}$, each comprising $2 \% \pm<1 \%$. In June and July 2014, group I brGDGTs were the most abundant, whereas in September 2014 and January 2015 reductions in group I brGDGTs were accompanied by increases in group III brGDGTs (Fig. 2). Overall, fluxes of brGDGTs were highest in September 2014 (ranging from 0.36 to $15.2 \mathrm{ng} \mathrm{m}^{-2} \mathrm{~d}^{-1}$ at different depths) (Fig. 3). In June and July 2014, total brGDGT fluxes at various depths ranged from 0.009 to 0.04 and 0.04 to $0.14 \mathrm{ng} \mathrm{m}^{-2} \mathrm{~d}^{-1}$, respectively (Fig. 3).

BrGDGT fluxes and distributions also varied as a function of depth (Figs. 3, 4, 5). In general, summed brGDGT fluxes increase with depth, with up to an order of magnitude higher fluxes at $30 \mathrm{~m}$ compared to $6 \mathrm{~m}$ for all dates (Fig. 3). 


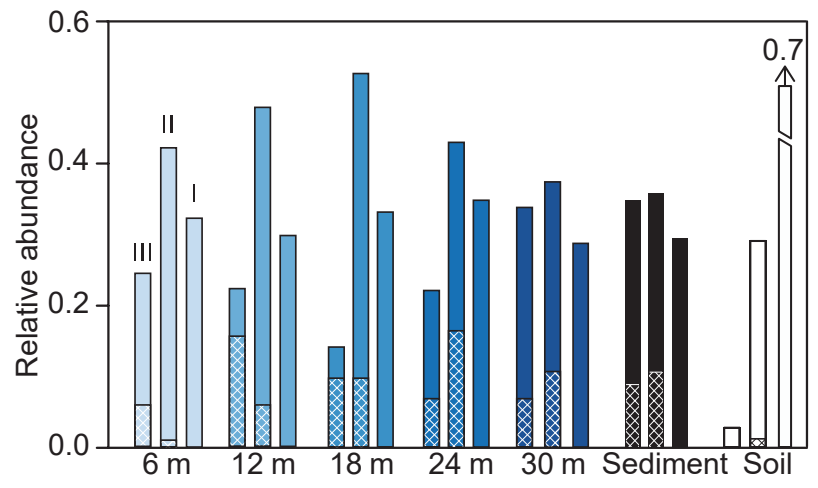

Figure 5. Spatial variation in the water column of the relative abundance of group I, II, and III brGDGTs in SPM as a function of water depth. For each group, the relative abundance at depths of 6 (lightest blue), 12, 18, 24, and $30 \mathrm{~m}$ (darkest blue) is plotted next to the average surface sediment (black) and catchment soil (white). For each category, brGDGT groups III, II, and I are shown in that order (left to right). Lines in each bar represent the relative abundance of 5and 6-methyl brGDGTs, with cross hatching representing 6-methyl abundances.

BrGDGT fluxes in the upper and lower water column peaked in September with fluxes of 0.4 to $0.6 \mathrm{ng} \mathrm{m}^{-2} \mathrm{~d}^{-1}$ and 7 to $16 \mathrm{ng} \mathrm{m}^{-2} \mathrm{~d}^{-1}$, respectively. The average distributions also changed as a function of depth. Group I brGDGTs comprised $30 \%$ of the distributions at all depths. Group II brGDGTs had the greatest abundance at 12 and $18 \mathrm{~m}$ in water depth (Fig. 5), comprising up to $50 \%$ of the distribution. Group III brGDGTs comprised an average of $30 \%$, with a peak of $35 \%$ at $30 \mathrm{~m}$ and a minimum at $18 \mathrm{~m}$ of $<20 \%$. These distributions lead to variations in $\mathrm{MBT}_{5 \mathrm{ME}}^{\prime}$ and $\mathrm{CBT}_{5 \mathrm{ME}}^{\prime}$ indices as a function of depth (Fig. 5). $\mathrm{MBT}_{5 \mathrm{ME}}^{\prime}$ varied from 0.34 to 0.46 and peaked at $24 \mathrm{~m}$ in water depth (Fig. 4). $\mathrm{CBT}_{5 \mathrm{ME}}^{\prime}$ varied from 1.1 to 1.6 , peaked at $12 \mathrm{~m}$, and then decreased with depth (Fig. 4).

\subsection{Surface sediment samples}

To represent surface sediments, we averaged the measurements from the uppermost $5 \mathrm{~cm}$ of core BP2014-5D, corresponding to approximately 70 years (Miller et al., 2017). BrGDGTs Ia, IIa, and IIIa dominate the distribution, with relative abundances of $27 \%, 32 \%$, and $33 \%$, respectively (Fig. 3). The next largest relative abundances are IIb, Ib, and IIIb (3\%, $2 \%$, and $1 \%$, respectively). $\mathrm{MBT}_{5 \mathrm{ME}}^{\prime}$ values in surface sediments range from 0.35 to 0.45 (Fig. 6).

\subsection{Sediment core}

BrGDGT concentrations in these samples ranged from 1.2 to 21.1 (median: 8.09 ) $\mu \mathrm{g} \mathrm{sed}^{-1}$. $\mathrm{MBT}_{5 \mathrm{ME}}^{\prime}$ ranged from 0.34 to 0.50 (median: 0.39$) \mu g \mathrm{~g} \mathrm{sed}^{-1}$. $\mathrm{MBT}_{5 \mathrm{ME}}^{\prime}$ values fluctuate around a stable mean from AD 1100 to 1400 , then broadly decrease from $\sim \mathrm{AD} 1400$ until the present day (Fig. 7). Decadal variability is superimposed on the longterm decreasing trend (Fig. 7). Prominent multi-decadal low-

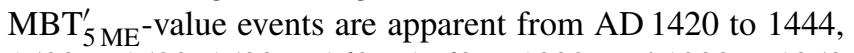
1500 to 1520,1593 to 1627,1762 to 1829 , and 1908 to 1950 (Fig. 7). Multi-decadal high-MBT ${ }_{5 \mathrm{ME}}^{\prime}$ events are observed from $\mathrm{AD} 1261$ to 1283,1317 to 1351,1556 to 1583,1632 to 1657, 1829 to 1846 , and 1958 to 1987 (Fig. 7). The brGDGT concentrations in the core range from 1.2 to $21.1 \mu \mathrm{g} \mathrm{sed}^{-1}$, with a median of $8.2 \mu \mathrm{g} \mathrm{sed}^{-1}$.

\subsection{BrGDGT isomer ratios}

The UHPLC method we utilized for brGDGT analysis (Hopmans et al., 2016) allows for the separation of 5- and 6methyl brGDGT isomers (DeJonge et al., 2013, 2014). Analysis of the relative abundances of these isomers has also been used to identify different production sources of brGDGTs (e.g., soils vs. water column; DeJonge et al., 2014; Weber et al., 2015). The summed IRs (Eq. 3) for soils, lake water, and sediments at Basin Pond are significantly different. The IR value for soils is very low and averages 0.03 , while the water samples and sediments are higher and average 0.26 and 0.30 , respectively (Fig. 6).

\subsection{Algal biomarkers}

Samples in the upper $17 \mathrm{~cm}$ of the sediment core were analyzed for the following algal lipid biomarkers: (iso)loliolide, $\mathrm{C}_{30}$ 1,13n-alkyl diol, dinosterol / stanol, and $\beta$-sitosterol / stanol. Concentrations of (iso)loliolide ranged from 31 to $426 \mu \mathrm{g} \mathrm{sed}^{-1} \quad($ median $=171) . \mathrm{C}_{30} 1,13 \mathrm{n}$ alkyl diol concentrations ranged from 8 to $1378 \mu \mathrm{g} \mathrm{g} \mathrm{sed}^{-1}$ $($ median $=475)$. Dinosterol $/$ stanol concentrations ranged from 12 to $5663 \mu \mathrm{g} \mathrm{sed}^{-1} \quad($ median $=1384)$. Concentrations of $\beta$-sitosterol / stanol concentrations ranged from 3 to $7955 \mu \mathrm{g} \mathrm{ged}^{-1}$ (median=1465).

\section{Discussion}

\subsection{Sources and seasonal production of Basin Pond brGDGTs}

It is important to constrain brGDGT sources before interpreting lacustrine sedimentary records. Multiple lines of evidence suggest brGDGTs deposited in Basin Pond sediments are predominantly produced within the water column, in agreement with prior studies (e.g., Tierney and Russell, 2009; Buckles et al., 2014; Loomis et al., 2014). First, we observe significant differences in the fractional abundances of brGDGTs among soil, SPM, and lake sediments (Figs. 2, 5), suggesting in situ production occurs in both soil and lacustrine environments, but that soil-derived brGDGTs do not exert a large influence on the Basin Pond sedimentary record. Average distributions of brGDGTs reveal that lake sediments 

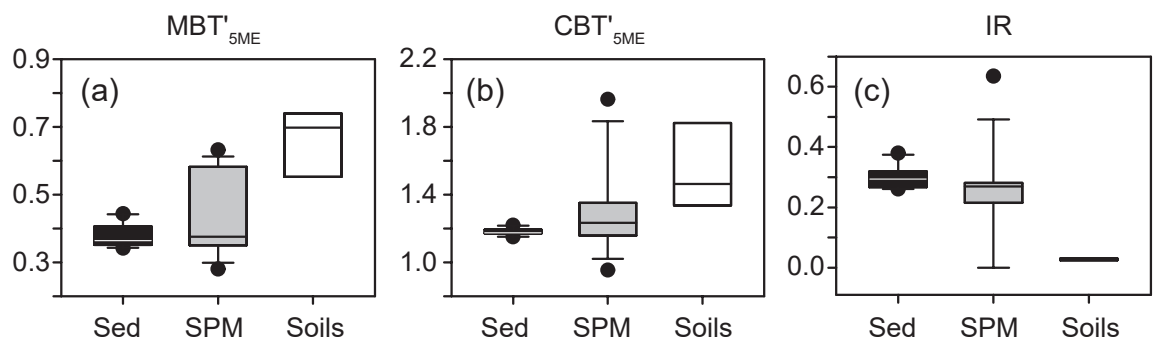

Figure 6. BrGDGT-based proxies measured on surface sediments (black), SPM (gray), and catchment soils (white). (a) Methylation of branched tetraethers $\left(\mathrm{MBT}_{5 \mathrm{ME}}^{\prime}\right)$. (b)Cyclization of branched tetraethers $\left(\mathrm{CBT}_{5 \mathrm{ME}}^{\prime}\right)$. (c) Isomer ratio (IR).

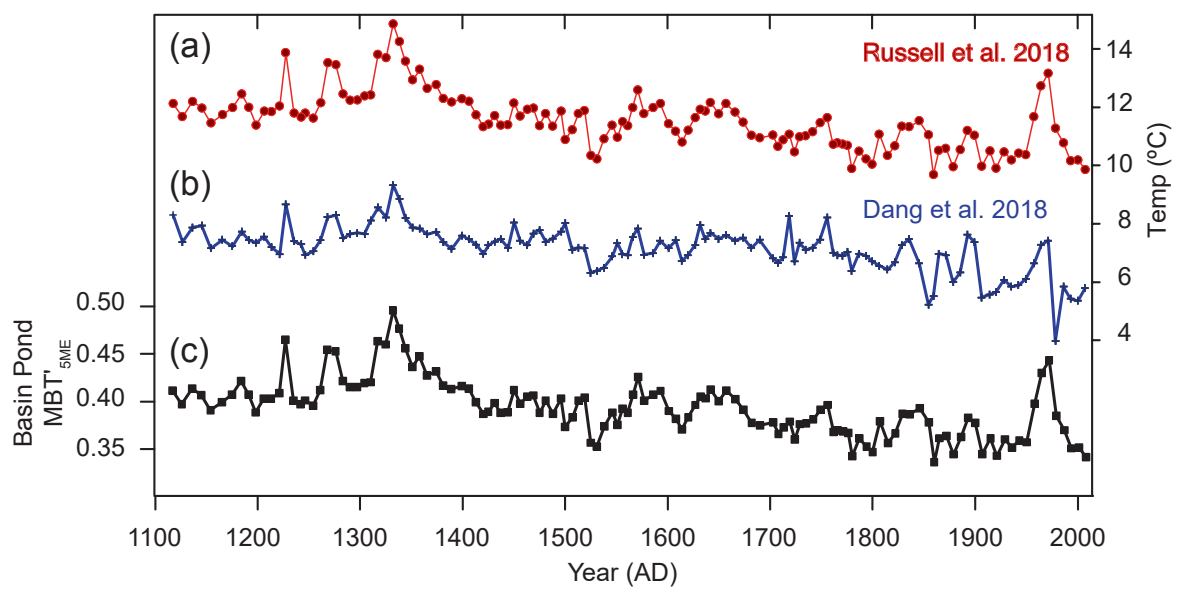

Figure 7. Comparison of Basin Pond $\mathrm{MBT}_{5 \mathrm{ME}}^{\prime}$ with newly published temperature calibrations. (a) Core BP2014-5D plotted using the African lakes calibration (Russell et al., 2018) and the (b) Chinese lakes calibration (Dang et al., 2018). (c) Basin Pond MBT ${ }_{5 \mathrm{ME}}$ values.

and SPM are similar in group I and III content, while the soils differ substantially (Figs. 2, 5). The relative amounts of 5- and 6-methyl brGDGTs also differ among soils, lake water, and sediment (Figs. 2, 5), as seen in the average IR values (Fig. 6). $\mathrm{MBT}_{5 \mathrm{ME}}^{\prime}$ and $\mathrm{CBT}_{5 \mathrm{ME}}^{\prime}$ values for lake sediment and soils are distinct, while SPM samples are similar to lake sediment samples, consistent with in situ brGDGT production within Basin Pond (Fig. 6). The degree of cyclization (mean $\left.\mathrm{CBT}_{5 \mathrm{ME}}^{\prime}=1.2\right)$ is significantly lower in lake sediments than in soil samples (mean $\left.\mathrm{CBT}_{5 \mathrm{ME}}^{\prime}=1.5\right)(p$ value $=0.021$ from two-tailed $t$ test), and brGDGTs are more methylated $(p$ value $=0.003)$ in lake sediments $\left(\right.$ mean $\left.\mathrm{MBT}_{5 \mathrm{ME}}^{\prime}=0.38\right)$ than in soils (mean $\mathrm{MBT}_{5 \mathrm{ME}}^{\prime}=0.7$ ) (Fig. 6). This agrees with differences in brGDGT distributions recorded in other temperate (Tierney et al., 2012; Wang et al., 2012; Loomis et al., 2014) and tropical (Tierney and Russell, 2009; Loomis et al., 2012; Buckles et al., 2014) lakes and catchment area soils and suggests in situ production of relatively more cyclized and methylated brGDGTs within lakes. In agreement with previous studies, we also note higher brGDGT concentrations in lake sediments (median $=8.2 \mu \mathrm{g} \mathrm{ged}^{-1}$ ) in comparison to watershed soils (median $=2.2 \mu \mathrm{g} \mathrm{ged}^{-1}$ ) (e.g.,
Sinninghe Damsté et al., 2009; Tierney and Russell, 2009), pointing to in situ brGDGT production.

BrGDGT fluxes at all depths are generally low throughout the summer months (June-July). A large flux increase at depth $(18-30 \mathrm{~m})$ occurs during September, when the lake is strongly stratified. Thus any transfer of brGDGTs from lower depths to the upper water column would likely be minimal. This suggests annual seasonal production of brGDGTs in Basin Pond, with a fall bloom occurring at intermediate $(18-30 \mathrm{~m})$ depths. Therefore, brGDGT temperatures recorded in the lake sediments likely reflect a seasonally biased (fall), rather than mean annual, temperature. We make the following observations based on these results. First, peak brGDGT flux is observed at $18-30 \mathrm{~m}$ in water depth, suggesting that the organisms producing the most brGDGTs thrive in the middle to upper water column (Fig. 3). Secondly, peak brGDGT production occurs in September, suggesting that the sedimentary record will be biased toward brGDGTs produced during this period (Fig. 3). Finally, for the four time periods sampled, brGDGT distributions (as described by $\mathrm{MBT}_{5 \mathrm{ME}}^{\prime}$ ) correlate with temperature (Fig. S1 in the Supplement). Interestingly, at depth the water temperature shows little to no seasonal cycle, remaining at approx- 


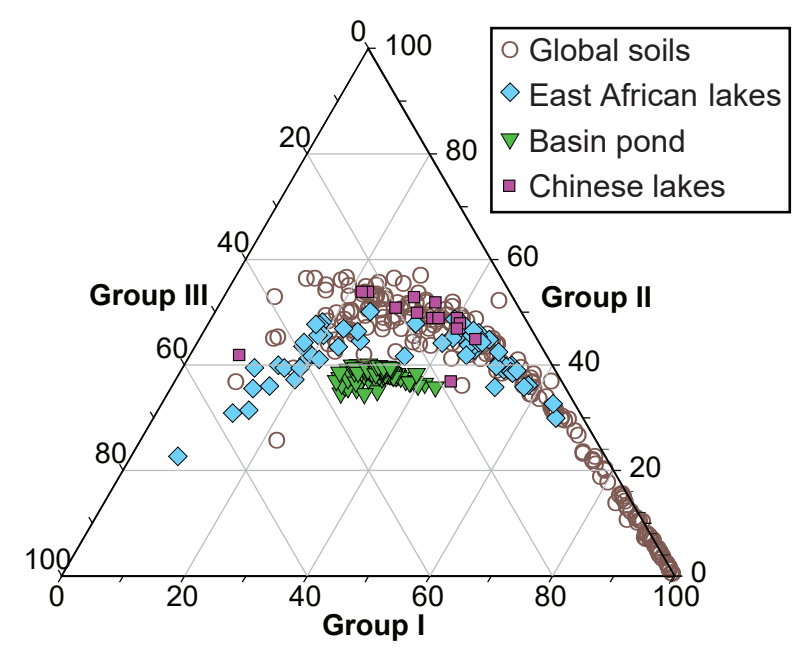

Figure 8. Ternary diagram of brGDGT distributions of lake sediments (Dang et al., 2018; Russell et al., 2018) and global soils (De Jonge et al., 2014a) and Basin Pond sediments.

imately $4{ }^{\circ} \mathrm{C}$ for the entire year (Frost, 2005). Therefore, if maximum brGDGT production is indeed occurring here, it is possible that another parameter, which covaries with temperature on a seasonal scale (i.e., light duration, water chemistry, nutrient availability), may drive, or contribute to, the distribution of brGDGTs produced at depth at Basin Pond. However, the sediment trap at this depth represents an integrated signal of SPM produced in the water column, which could also be driving the temperature correlation at depth.

Although few studies are available for comparison, Loomis et al. (2014) studied brGDGTs in another temperate lake in the NE US (lower King Pond, Vermont). The brGDGT production in lower King Pond peaked during fall and spring and was linked to seasonal full water column mixing events (Loomis et al., 2014), which do not occur at Basin Pond (Frost, 2005). Moreover, Basin Pond is 10 times larger by area and 4 times deeper than lower King Pond. Similar to lower King Pond, brGDGT production at Basin Pond seems to be seasonal, and calibration of brGDGTs against seasonal (in this case, fall) temperatures is a necessary area of future work to accurately reconstruct past absolute temperature change for this location. If the behavior of brGDGTs in lower King Pond and Basin Pond is representative of all temperate lakes, then calibration to fall or spring temperature may be the most appropriate choice for these settings.

\subsection{Calibration of the 900-year brGDGT record to temperature}

Numerous studies have provided strong evidence for in situ brGDGT production in lakes and have shown that application of the global soil calibration to lacustrine sediments often yields temperatures that are unrealistically cold (e.g., Tier- ney and Russell, 2009; Bechtel et al., 2010; Blaga et al., 2010; Tierney et al., 2010a, b; Tyler et al., 2010; Pearson et al., 2011). Therefore, many lacustrine brGDGT calibrations have been developed (e.g., Tierney et al., 2010; Zink et al., 2010; Pearson et al., 2011; Sun et al., 2011; Loomis et al., 2012, Foster et al., 2016). However, many of these are based on relatively few samples or are geographically restricted (e.g., Tierney et al., 2010; Zink et al., 2010; Foster et al., 2016). Furthermore, at present, all available lacustrine brGDGT calibrations except for two (Dang et al., 2018; Russell et al., 2018) were developed using older HPLC methods that did not fully separate brGDGT isomers. As we measured our brGDGTs following the newer method of Hopmans et al. (2016), we investigated Basin Pond temperature reconstructions using only those calibrations based on the same technique. The Dang et al. (2018) calibration is based on alkaline Chinese lakes and reconstructs temperatures ranging from 4 to $9^{\circ} \mathrm{C}$, while the Russell et al. (2018) calibration is based on African lakes and yields temperatures ranging from 10 to $14^{\circ} \mathrm{C}$ (Fig. 7). The African lakes calibration from Russell et al. (2018) is based on $\mathrm{MBT}_{5 \mathrm{ME}}^{\prime}$, while the Chinese lakes calibration of Dang et al. (2018) is based on fractional abundances of brGDGTs; therefore these two calibrations yield somewhat different trends, with the Dang et al. (2018) calibration showing muted variability and some discrepancies from the other proxy records (i.e., during the last 50 years) (Fig. 7).

Importantly, caution must be taken when interpreting the Basin Pond reconstructed temperatures using either of these calibrations because application of an African or Chinese calibration to lakes in the NE US is questionable as these regions are climatically different and their lakes differ in terms of stratification and mixing regimes. Furthermore, brGDGTs from Basin Pond are characterized by distinct brGDGT distributions from both the African (Russell et al., 2018) and alkaline Chinese lake sediments (Dang et al., 2018) (Fig. 8). This suggests that application of either of these calibrations to Basin Pond sediments may not be appropriate. Local temperature data are available for Basin Pond over the period our measurements were made, but the SPM dataset presented here is not large enough to develop a robust local $\mathrm{MBT}_{5 \mathrm{ME}}^{\prime}$ to temperature calibration (see Supplement). We thus present our results in the following discussion and figures simply in terms of the $\mathrm{MBT}_{5 \mathrm{ME}}^{\prime}$ index, which provides a relative temperature indicator, in which higher values reflect relatively higher temperatures and vice versa (De Jonge et al., 2014b).

Our interpretation of the 900 -year $\mathrm{MBT}_{5 \mathrm{ME}}^{\prime}$ record is as follows. Based on the SPM samples, we argue that the down-core brGDGT reconstruction is likely weighted toward September temperature change in the NE US. We note that brGDGTs are present at all depths measured but peak at 18$30 \mathrm{~m}$ in depth, indicating that the compounds reaching the lake floor represent an integrated signal from the entire water column. Although brGDGT concentrations vary downcore, they are not correlated with reconstructed $\mathrm{MBT}_{5 \mathrm{ME}}^{\prime}$ 


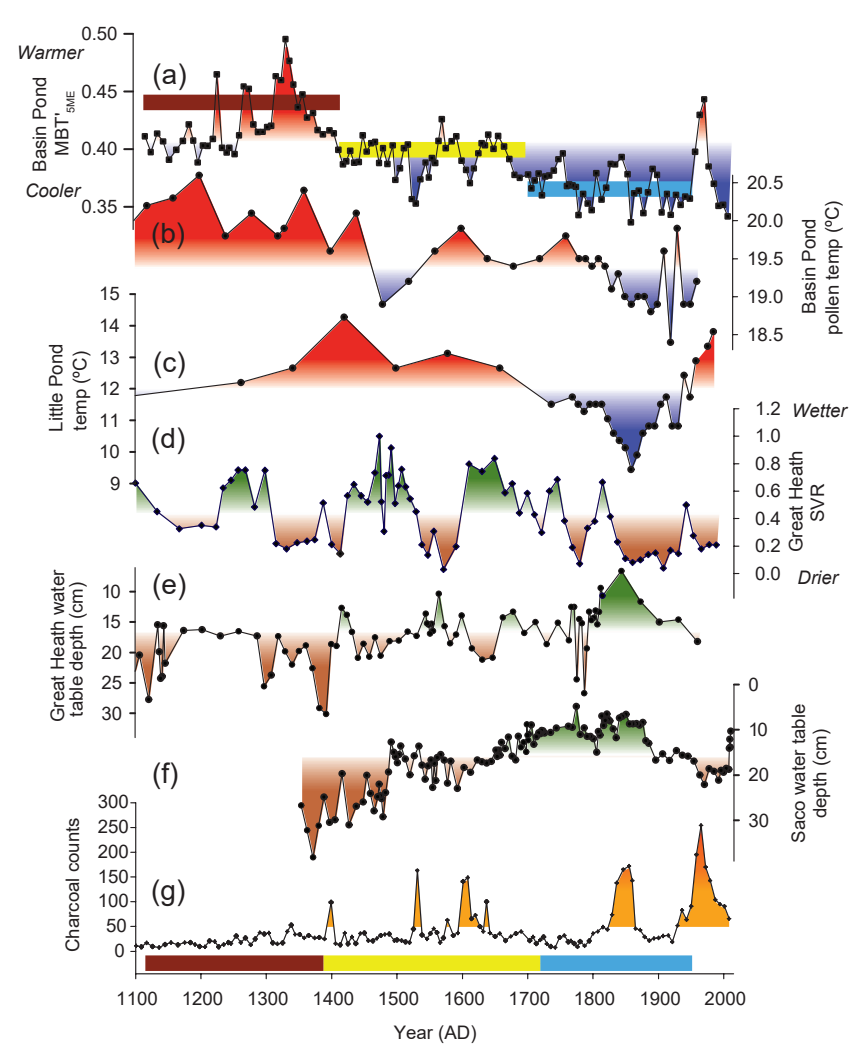

Figure 9. The Basin Pond $\mathrm{MBT}_{5 \mathrm{ME}}^{\prime}$ record compared with other paleoclimate records from the NE US. (a) $\mathrm{MBT}_{5 \mathrm{ME}}^{\prime}$ (this study). Colored bars indicate the three main periods discussed in the text. (b) Pollen-based reconstruction of temperature at Basin Pond (Gajewski, 1988). (c) Temperature reconstruction based on deuterium isotopes $(\delta \mathrm{D})$ at Little Pond (Gao et al., 2017). (d) Great Heath aridity reconstruction based on the Sphagnum / vascular ratio (SVR) (Nichols and Huang, 2012). (e) Water table reconstruction from Great Heath (Clifford and Booth, 2013). (f) Water table reconstruction from Saco Bog (Clifford and Booth, 2013). (g) Charcoal counts from Basin Pond (Miller et al., 2017).

values $(p=0.25)$, indicating that brGDGT production and $\mathrm{MBT}_{5 \mathrm{ME}}^{\prime}$ variability are largely decoupled. We observe an overall stepped cooling trend recorded by generally decreasing $\mathrm{MBT}_{5 \mathrm{ME}}^{\prime}$ values over the past 900 years (Fig. 9). Using the calibration of Russell et al. (2018), this overall cooling is on the order of $3.0^{\circ} \mathrm{C}$; however, for the reasons discussed earlier, we advise that caution must be taken when interpreting absolute temperature changes from applying this calibration to Basin Pond sediments.

\subsection{Comparison to regional hydroclimate records in the NE US}

Regional hydroclimate in the NE US has been reconstructed at several sites on similar timescales as the Basin Pond record. The $\mathrm{MBT}_{5 \mathrm{ME}}^{\prime}$ record indicates an overall cooling from $\sim$ AD 1300 to $\sim$ AD 1900 (Fig. 9), which is also ob- served in pollen-derived temperature reconstructions from Basin Pond (Gajewski, 1988). Both records also indicate two major cooling steps, although the exact timing of these differs among records, which may be attributable to age model differences (Fig. 9). Apparent differences among the Basin Pond records are likely also associated with sampling resolution; the pollen record has varying and generally much lower sample resolution in comparison to our $\mathrm{MBT}_{5 \mathrm{ME}}^{\prime}$ record. Furthermore, some of the differences in $\mathrm{MBT}_{5 \mathrm{ME}}^{\prime}$ and pollen reconstructions may be caused by differences in proxy seasonality, with pollen representing a summer signal (Gajewski, 1988) and $\mathrm{MBT}_{5 \mathrm{ME}}^{\prime}$ likely representing a fall signal.

The general long-term cooling trend from Basin Pond is also observed in a hydrogen isotope-based temperature reconstruction from Little Pond, Massachusetts (Gao et al., 2017). Both records show higher temperatures between AD 1300 and 1400 (Fig. 9). Bog records provide additional high-resolution reconstructions of hydrological conditions in the NE US over this time period via analysis of testate amoeba (a proxy for water table depth) and the Sphagnum / vascular ratio (SVR) (Nichols and Huang, 2012; Clifford and Booth, 2013). The testate amoeba records show that the last 400 years (i.e., AD 1600-2000) have been generally wetter than the preceding 400 years (AD 1200-1600). However, unlike the temperature reconstructions, these records do not show a long-term linear trend (Fig. 9).

These cooling and wetting trends are surprising given the record of fire history at Basin Pond (Miller et al., 2017), which shows five periods of increased charcoal deposition since AD 1100 (Fig. 9). It is important to note that wildfire activity is a complex phenomena, with multiple factors affecting fire occurrence apart from climate variability (Marlon et al., 2017). However, our data suggest that fire activity in the NE US may be influenced more by shorterterm (multi-decadal) variations in climate, particularly seasonal cooling superimposed on dry conditions, as opposed to longer-term multi-centennial climate trends. Surprisingly, the first 200 years of the record (AD 1100-1300) are dominated by warm and dry conditions, but no fire events were recognized during this period. Three fire events (Fig. 9g), between $\sim \mathrm{AD} 1300$ and $\sim \mathrm{AD} 1700$, are associated with regionally dry conditions (Fig. 9d-f). Although average Basin Pond $\mathrm{MBT}_{5 \mathrm{ME}}^{\prime}$ values are higher on a multi-centennial timescale during this interval, the fire events themselves occur synchronously with multi-decadal cold periods (Fig. 9a-c). Furthermore, two recent fire events occurred during the historical period, which is reconstructed as relatively cool and wet (Fig. 9). Therefore, it appears that at Basin Pond, temperature did not exert a major influence over fire occurrence.

\subsection{Comparison with Northern Hemisphere records}

A compilation of Northern Hemisphere temperature records for the last 2000 years reveals sustained warmth from AD 830 to 1100, just prior to the beginning of our reconstruc- 


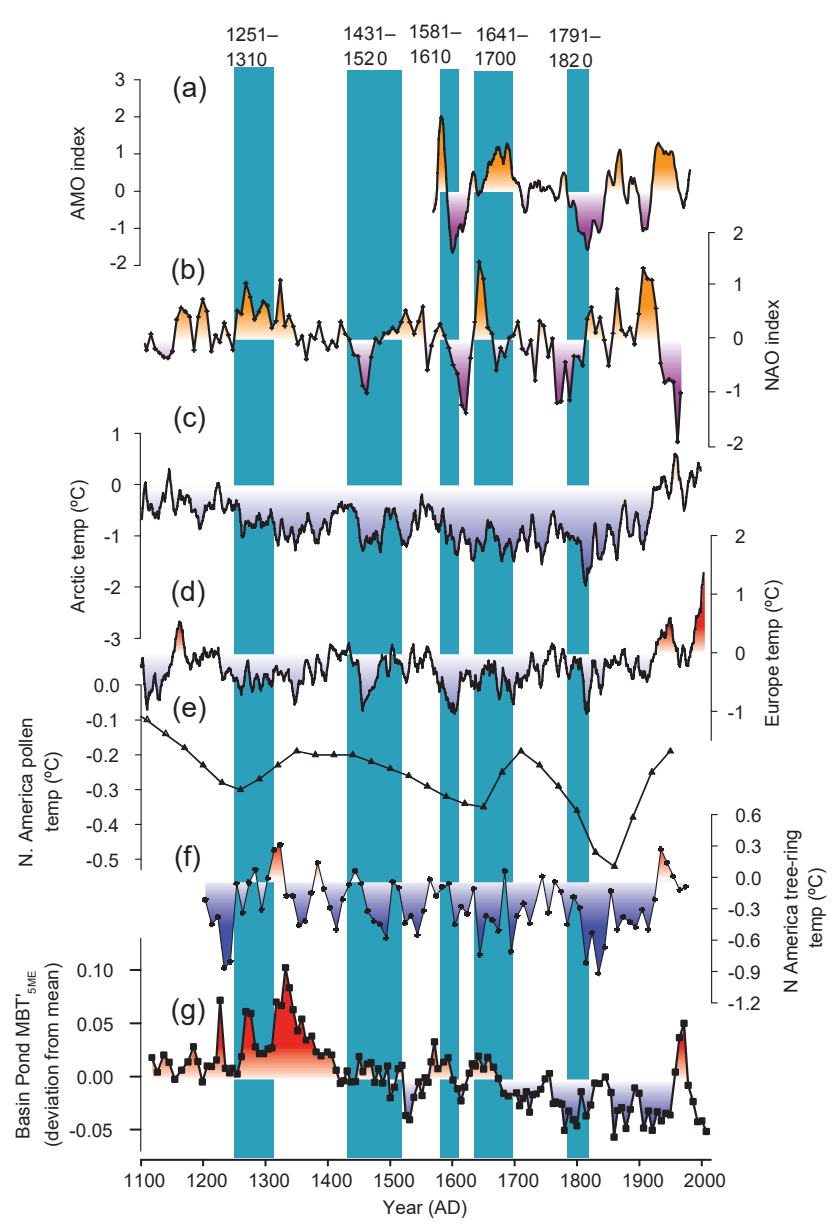

Figure 10. The Basin Pond $\mathrm{MBT}_{5 \mathrm{ME}}^{\prime}$ record compared with regional and global records of temperature change. (a) Tree-ringbased reconstruction of the AMO index (Gray et al., 2004). (b) NAO index reconstruction (Sun et al., 2015). (c-f) Regional temperature stacks based on composite proxy reconstructions for the Arctic (c), Europe (d), and North America (pollen) (e); tree rings (f). The records have been standardized to have the same mean $(0)$ and standard deviation (1) from AD 1190 to 1970 (PAGES2k 2013). (g) $\mathrm{MBT}_{5 \mathrm{ME}}^{\prime}$ (this study).

tions (PAGES2k, 2013). Northern Hemisphere climate then entered a cooler phase, though the timing of this transition varied regionally between AD 1200 and 1500 (PAGES2k, 2013). North American pollen data show elevated, though decreasing, temperatures through AD 1500 (Gajewski, 1988; PAGES2k, 2013) (Fig. 10). From AD 1100 to 1400, Basin Pond $\mathrm{MBT}_{5 \mathrm{ME}}^{\prime}$ values are high in contrast with European and Arctic temperature reconstructions. From AD 1500 to $1900, \mathrm{MBT}_{5 \mathrm{ME}}^{\prime}$ values are lower, in better agreement with other Northern Hemisphere reconstructions. Moreover, the decadal- to centennial-scale variability observed in $\mathrm{MBT}_{\mathrm{SME}}^{\prime}$ and other records during this time may be linked to variability in Atlantic Multi-decadal Oscillation (AMO) and North Atlantic Oscillation (NAO) indices (Fig. 8). We note that the
brGDGT $\mathrm{MBT}_{5 \mathrm{ME}}^{\prime}$ values are better correlated with regional tree-ring records and compilations of European and Arctic temperatures, which all show warm anomalies followed by cooling, earlier this century. Thus, the multi-centennial structure of the brGDGT record from Basin Pond is supported by other local, regional, and global records (PAGES2k, 2013). On a multi-decadal scale, there is variability potentially associated with volcanic events recognized as having a global impact. Five intervals during the last millennium were defined as "volcanic-solar downturns": AD 1251-1310, 14311520, 1581-1610, 1641-1700, and 1791-1820 (PAGES2k, 2013). All but the most recent (AD 1908-1950) of the cool events are present in the Basin Pond $\mathrm{MBT}_{5 \mathrm{ME}}^{\prime}$ record during these periods (or within the age model uncertainty) (Fig. 10 highlighted in blue).

There is some similarity between the Basin Pond reconstruction and other Northern Hemisphere reconstructions (PAGES2k, 2013) (Fig. 10). The brGDGT record is also peppered with warm (high $\mathrm{MBT}_{5 \mathrm{ME}}^{\prime}$ ) anomalies; many of these seem to be coherent with tree-ring-based reconstructions of North American climate (i.e., AD 1300, 1550, 1830) and are sometimes associated with negative phases of the NAO. The sensitivity of the Basin Pond sediment record to regional-scale climatic variations is highlighted by time series analysis. Multispectral taper method analysis reveals a persistent cycle in the brGDGT-based temperature reconstruction with a period of 57-63 years (Fig. 10). The Northern Hemisphere tree-ring compilation also shows a cyclicity with a period of 60 years (Fig. 10). However, the fact that the two datasets are not significantly correlated indicates the variability at 60-year periods is not exactly in phase over the 900 -year period covered by the two records. Crosscorrelation analysis indicates that the correlation between the two datasets is strongest when the tree-ring reconstruction is lagged by 42 years relative to the Basin Pond temperature record $(r=0.33, p=0.04)$. Significant spectral peaks with a similar period exist in the annually resolved records from Europe (period $=65$ years), Asia (period $=58$ years), and the Arctic (period = 58 years) (PAGES2k, 2013). However, the same analyses applied to South American, Australasian, and Antarctic reconstructions do not show spectral peaks at this period (PAGES2k, 2013). Thus, it appears that the Basin Pond brGDGT record captures variability that is representative of, but not necessarily in phase with, the Northern Hemisphere at large. One possible mechanism to explain this is the NAO, which exhibits a quasi-periodic oscillation of $\sim 60$ years (Sun et al., 2015). While the NAO has some regionally coherent climatic effects, the signature of positive and negative NAO modes is spatially heterogeneous and complex; this could explain the phase offset in the $\sim 60$-year band between the Basin Pond record and the other Northern Hemisphere reconstructions.

Another possible driver of the $\mathrm{MBT}_{5 \mathrm{ME}}^{\prime}$ changes we see is the AMO, which is based on sea surface temperature anomalies in the North Atlantic and shows variability in quasi- 


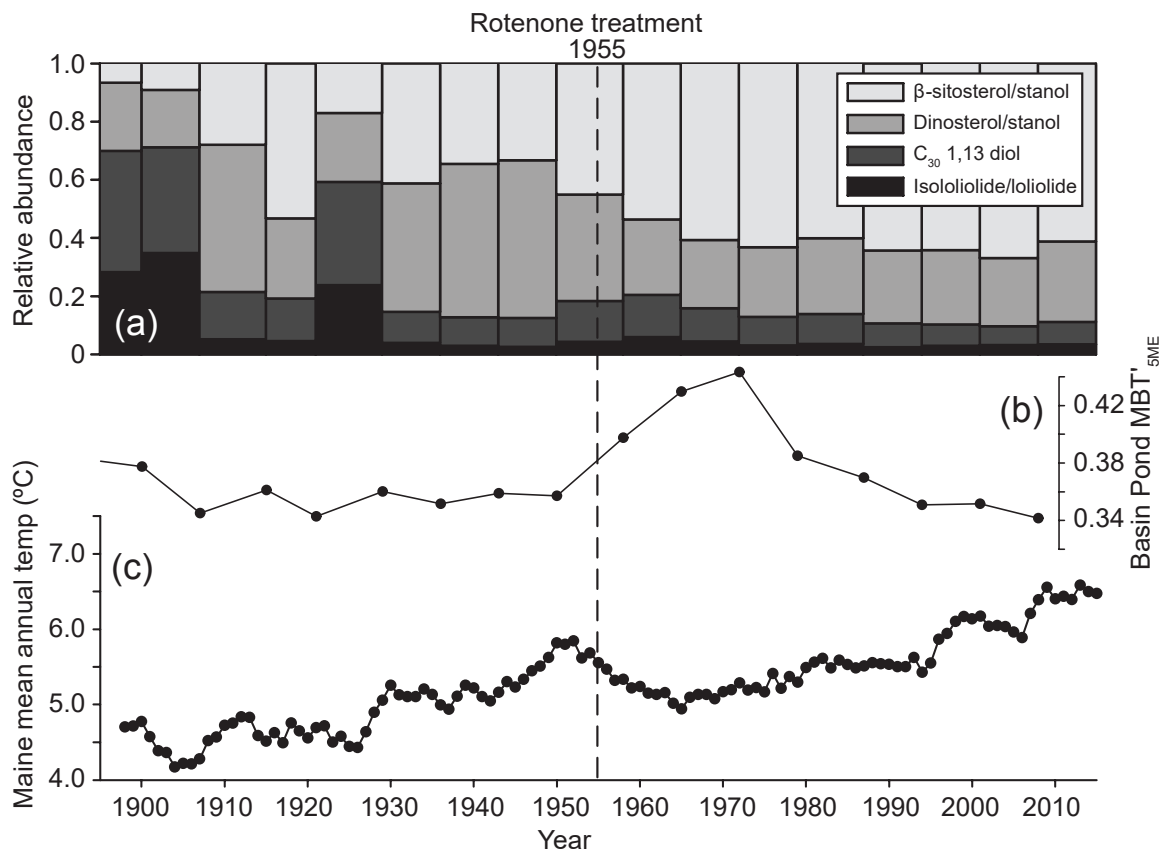

Figure 11. Comparison of historical temperature records for the state of Maine, $\mathrm{MBT}_{5 \mathrm{ME}}^{\prime}$ reconstruction, and algal lipid biomarkers in Basin Pond. (a) Relative abundance of four major algal lipids. (b) $\mathrm{MBT}_{5 \mathrm{ME}}^{\prime}$ record. (c) Maine statewide average temperature (NOAA, 2014). The black line indicates the rotenone treatment of the lake in 1955.

periodic 60-80-year cycles (Trenberth et al., 2017). An AMO reconstruction spanning the last 400 years shows some similarities to the $\mathrm{MBT}_{5 \mathrm{ME}}^{\prime}$ reconstruction from Basin Pond. Although the records do not show a strong cross correlation $(r=0.08, p=0.53)$, they feature apparently synchronous cool and warm periods (i.e., AD 1550-1650 and 1780-1830) (Fig. 10). This suggests that climate at Basin Pond is coupled to Atlantic sea surface temperatures on multi-decadal timescales. Thus, the record presented here may prove useful in the future for reconstructing changes in the AMO earlier in the paleorecord.

\subsection{0th century temperature, brGDGT reconstructions, and algal community shifts}

Daily temperature averages from meteorological stations in the state of Maine were accessed and obtained through the National Climatic Data Center from 1895 to the present day (NOAA, 2014) (Fig. 11). Average temperatures in Maine have warmed by $\sim 1.5^{\circ} \mathrm{C}$ since $\mathrm{AD} 1895$ (Fig. 11). The temperature increase is dominated by changes from AD 1895 to 1945 and 1985 to the present; for the 40 intervening years mean temperatures were more stable, with a slight cooling observed during fall (Fig. 11). Interannual variability in $\pm 1{ }^{\circ} \mathrm{C}$ is observed throughout the record, with the most pronounced variability during the winter (NOAA, 2014).

Interestingly, variations in $\mathrm{MBT}_{5 \mathrm{ME}}^{\prime}$ values for the last 100 years do not agree with instrumental observations. The brGDGT-based reconstruction shows stable values from
AD 1900 to 1950, followed by an abrupt increase (warming) in $\mathrm{MBT}_{5 \mathrm{ME}}^{\prime}$ of 0.1 until approximately AD 1975 (three data points) and a subsequent continual decrease since then (five data points) (Fig. 11). In contrast, instrumental records indicate a slight cooling, or at least a stabilization of warming, starting at the same time (1960s-1970s) when the $\mathrm{MBT}_{5 \mathrm{ME}}^{\prime}$ values increase (Fig. 11). We note decreasing $\mathrm{MBT}_{5 \mathrm{ME}}^{\prime}$ values in the upper $3.5 \mathrm{~cm}$ (Fig. 11). Low $\mathrm{MBT}_{5 \mathrm{ME}}^{\prime}$ values in surface and core top sediments have been noted in other studies as well (e.g., Sinninghe Damsté et al., 2012; Tierney et al., 2012), indicating that this feature occurs in different regions and environments and may be driven by mechanisms associated with brGDGT production or preservation. Tierney et al. (2012) note a similar pattern in the brGDGT distributions of Salt Pond, Rhode Island, surface sediments that we observe at Basin Pond where the shallow surface sediments are characterized by more methylated brGDGTs. These authors suggest that more methylated brGDGTs present in shallow lake sediments do not survive diagenesis and they also note that deeper sediments yielded reasonable brGDGT reconstructed temperatures (Tierney et al., 2012). This hypothesis requires further testing, and, additionally, other influences such as changes in brGDGT producers, postdepositional mobility and/or overprinting of the brGDGT signal, biotic and abiotic compound diagenesis, and anthropogenic impacts to lake ecosystems should be examined as well. Despite the uncertainties about the $\mathrm{MBT}_{5 \mathrm{ME}}^{\prime}$ record during the last 100 years, we believe that the Basin Pond brGDGT 
record is useful for describing regional climate evolution over the last millennium in the NE US.

It is possible that land-use change and other anthropogenic impacts have affected the brGDGT record over the last 100 years. However, known land use change in the Basin Pond catchment is minimal over the past century (Gajewski, 1988). A complicating factor is the addition of the piscicide rotenone to the lake in 1955 to remove fish species in competition with trout (USGS, 1996). While the estimated lifetime of rotenone in the water column is short (days to weeks), it has been shown to have lasting long-term (years) effects on zooplankton communities and lake productivity (Kiser, 1963; Andersen, 1970; Sanni and Waervagen, 1990).

In lacustrine environments, some classes of lipid biomarkers, specifically sterols and stanols, can give valuable insight into variability in lake productivity of certain types of algae throughout time. Many sterols (and their saturated counterparts, stanols) are indicative of certain groups of source organisms, in particular, specific phytoplankton groups (e.g., Volkman et al., 1998; Volkman, 2003). For example, dinosterol and dinostanol are found in dinoflagellates and are not produced in higher plants and are therefore used as a biomarker for dinoflagellate species (Volkman et al., 1998). The compounds (iso)loliolide and loliolide are known to be anoxic degradation products of diatom pigments (Klok et al., 1984; Repeta, 1989) while long-chain alkyl diols are produced by eustigmatophyte (yellow-green) algae (Volkman et al., 1998). At Basin Pond, several algal biomarker concentrations, including isololiolide / loliolide, dinosterol / stanol, and $\mathrm{C}_{30} 1,13 n$-alkyl diol, decrease following the rotenone treatment in $\mathrm{AD} 1955$ while $\beta$-sitosterol (a biomarker of higher plants) increases (Fig. 11), suggesting a shift in the overall algal community structure. Additionally, after 1955 contributions of the different algal biomarkers are remarkably stable in comparison to earlier times (Fig. 11). Due to the widespread shift in the algal community, we posit that bacterial communities and therefore brGDGT production may also have been impacted. However, brGDGT concentrations do not clearly respond to the rotenone treatment, and additional knowledge of brGDGT producers would be required to further investigate this idea.

\section{Conclusions}

We find evidence for seasonally biased in situ production of branched glycerol dialkyl glycerol tetraethers (brGDGTs) in a lake in central Maine, NE US. BrGDGTs are mostly produced in September at Basin Pond, and their downward fluxes in the water column peak at $30 \mathrm{~m}$ in water depth. A down-core brGDGT-based reconstruction reveals both gradual and transient climate changes over the last 900 years and records cooling and warming events correlated with other Northern Hemisphere records and the NAO and AMO indices. This suggests inland Maine climate is sensitive to hemispheric climate forcing as well as changes in regional atmospheric pressure patterns and North Atlantic sea surface temperatures. Our new $\mathrm{MBT}_{5 \mathrm{ME}}^{\prime}$ temperature reconstruction, supported by a pollen record from the same site, reveals a prominent cooling trend from AD 1100 to 1900 in this area. Comparison with regional hydroclimate records suggests that despite increasingly cool and wet conditions persisting at Basin Pond over the last 900 years, fire activity has increased. Although recent fire activity is likely anthropogenically triggered (i.e., via land-use change), our results imply an independent relationship between climate and NE US fire occurrence over the study interval. Thus, the paleotemperature reconstruction presented here alongside site-specific knowledge from Basin Pond informs our understanding of climatic variability in the NE US beyond the era of human influence.

Data availability. BrGDGT data, including fractional abundances of 5- and 6-methyl isomers, BIT index values, $\mathrm{MBT}_{5 \mathrm{Me}}^{\prime}$ values, $\mathrm{CBT}_{5 \mathrm{Me}}^{\prime}$ values, 5-methyl isomer ratio (IR), total brGDGT concentrations, and temperature calibrations (Dang et al., 2018; Russell et al., 2018) from Basin Pond watershed soils, SPM, and sediment samples are available at the National Oceanic and Atmospheric Administration National Centers for Environmental Information (NOAA NCEI) Paleoclimate Database (https://www.ncdc.noaa. gov/paleo/study/25470). Concentrations of isololiolide/loliolide, C30 1,13 diol, sitosterol / sitostanol, and dinosterol / dinostanol from the Basin Pond sediment core are also provided where measured. To access these data, please visit https://www.ncdc.noaa.gov/ data-access/paleoclimatology-data/datasets (Miller et al., 2018).

Supplement. The supplement related to this article is available online at: https://doi.org/10.5194/cp-14-1653-2018-supplement.

Author contributions. DRM, MHH, and BAK designed the sediment traps, carried out field work, processed samples through all stages of laboratory prep and analysis, and prepared the paper for publication. ISC and RSB provided advice throughout the experiment and writing process, aided with field work, contributed to data interpretation, and covered costs of sample analysis. Paper revisions were made through contributions from all co-authors.

Competing interests. The authors declare that they have no conflict of interest.

Acknowledgements. The authors thank John Sweeney for his assistance in sediment trap construction and design. Jeff Salacup is acknowledged for technical laboratory assistance. We thank the members of the UMass Biogeochemistry Lab for helpful feedback and discussion. We are grateful to Lucas Groat, Christopher Mode, and Paige Miller-Hughes for their assistance in sediment trap deployment and collection. Mike Retelle, Dan Frost, Julie Savage, and the Bates College Geology Department are recognized for 
sediment coring assistance. We are indebted to the Basin, David, and Tilton Ponds Association for their cooperation and support. Funding for this project was provided by grant G12AC00001 from the United States Geological Survey and the 2014 and 2015 Joe Hartshorn Memorial Award through the UMass Amherst Department of Geosciences. We thank Juzhi Hou and the anonymous reviewer for their comments. We also acknowledge Liping Zhou and Denis-Didier Rosseau for editing this paper. Results are solely the responsibility of the authors and do not necessarily represent the views of the Northeast Climate Adaptation Science Center or the USGS.

Edited by: Denis-Didier Rousseau

Reviewed by: Juzhi Hou and one anonymous referee

\section{References}

Anderson, R. S.: Effects of Rotenone on Zooplankton Communities and a Study of their Recovery Patterns in Two Mountain Lakes in Alberta, J. Fish. Res. Board Can., 27, 1335-1356, 1970.

Bechtel, A., Smittenberg, R. H., Bernasconi, S. M., and Schubert, C. J.: Distribution of branched and isoprenoid tetraether lipids in an oligotrophic and a eutrophic Swiss lake: Insights into sources and GDGT-based proxies, Org. Geochem., 41, 822-832, 2010.

Blaga, C. I., Reichart, G. J., Schouten, S., Lotter, A. F., Werne, J. P., Kosten, S., Mazzeo, N., Lacerot, G., and Sinninghe Damsté, J. S.: Branched glycerol dialkyl glycerol tetraethers in lake sediments: Can they be used as temperature and $\mathrm{pH}$ proxies?, Org. Geochem., 41, 1225-1234, 2010.

Buckles, L. K., Weijers, J. W. H., Verschuren, D., and Sinninghe Damsté, J. S.: Sources of core and intact branched tetraether membrane lipids in the lacustrine environment: Anatomy of Lake Challa and its catchment, equatorial East Africa, Geochim. Cosmochim. Ac., 140, 106-126, 2014.

Clifford, M. J. and Booth, R. K.: Increased probability of fire during late Holocene droughts in northern New England, Climatic Change, 119, 693-704, 2013

Colcord, D. E., Cadieux, S. B., Brassell, S. C., Castañeda, I. S., Pratt, L. M., and White, J. R.: Assessment of branched GDGTs as temperature proxies in sedimentary records from several small lakes in southwestern Greenland, Org. Geochem., 82, 33-41, 2015.

Dang, X., Ding, W., Yang, H., Pancost, R. D., Naafs, B. D. A., Xue, J., Lin, X., Lu, J., and Xie, S.: Different temperature dependence of the bacterial brGDGT isomers in 35 Chinese lake sediments compared to that in soils, Org. Geochem., 119, 72-79, 2018.

De Jonge, C., Hopmans, E. C., Stadnitskaia, A., Rijpstra, W. I. C., Hofland, R., Tegelaar, E., and Sinninghe Damsté, J. S.: Identification of novel penta- and hexamethylated branched glycerol dialkyl glycerol tetraethers in peat using HPLC-MS2, GC-MS and GC-SMB-MS, Org. Geochem., 54, 78-82, 2013.

De Jonge, C., Hopmans, E. C., Zell, C. I., Kim, J.-H., Schouten, S., and Sinninghe Damsté, J. S.: Occurrence and abundance of 6-methyl branched glycerol dialkyl glycerol tetraethers in soils: Implications for palaeoclimate reconstruction, Geochim. Cosmochim. Ac., 141, 97-112, 2014a.

De Jonge, C., Stadnitskaia, A., Hopmans, E. C., Cherkashov, G., Fedotov, A., and Sinninghe Damsté, J. S.: In situ pro- duced branched glycerol dialkyl glycerol tetraethers in suspended particulate matter from the Yenisei River, Eastern Siberia, Geochim. Cosmochim. Ac., 125, 476-491, https://doi.org/10.1016/j.gca.2013.10.031, 2014b.

De Jonge, C., Stadnitskaia, A., Hopmans, E. C., Cherkashov, G., Fedotov, A., Streletskaya, I. D., Vasiliev, A. A., and Sinninghe Damsté, J. S.: Drastic changes in the distribution of branched tetraether lipids in suspended matter and sediments from the Yenisei River and Kara Sea (Siberia): Implications for the use of brGDGT-based proxies in coastal marine sediments, Geochim. Cosmochim. Ac., 165, 200-225, 2015.

Foster D. R. and Aber, J. D. (Eds.): Forests in Time: The Environmental Consequences of 1,000 Years of Change in New England, Yale University Press, New Haven, CT, USA, 2004.

Foster, L. C., Pearson, E. J., Juggins, S., Hodgson, D. A., Saunders, K. M., Verleyen, E., and Roberts, S. J.: Development of a regional glycerol dialkyl glycerol tetraether (GDGT) - temperature calibration for Antarctic and sub-Antarctic lakes, Earth Planet. Sc. Lett., 433, 370-379, 2016.

Frost, D. S.: Paleoclimate Reconstruction using Physical Sedimentology and Organic Matter Biogeochemistry if Varved Sediments, Basin Pond, Fayette, ME (Undergraduate Thesis), Bates College, 2005.

Gajewski, K.: Late holocene climate changes in eastern North America estimated from pollen data, Quaternary Res., 29, 255262, 1988.

Gajewski, K., Swain, A. M., and Peterson, G. M.: Late Holocene Pollen Stratigraphy in Four Northeastern United States Lakes, Géographie physique et Quaternaire, 41, 377-386, 1987.

Gao, L., Huang, Y., Shuman, B., Oswald, W. W., and Foster, D.: A high-resolution hydrogen isotope record of behenic acid for the past $16 \mathrm{kyr}$ in the northeastern United States, Quatern. Int., 449, 1-11, 2017.

Hopmans, E. C., Weijers, J. W. H., Schefuß, E., Herfort, L., Sinninghe Damsté, J. S., and Schouten, S.: A novel proxy for terrestrial organic matter in sediments based on branched and isoprenoid tetraether lipids, Earth Planet. Sc. Lett., 224, 107-116, 2004.

Hopmans, E. C., Schouten, S., and Sinninghe Damsté, J. S.: The effect of improved chromatography on GDGT-based palaeoproxies, Org. Geochem., 93, 1-6, 2016.

Horton, R., Yohe, G., Easterling, W., Kates, R., Ruth, M., Sussman, E., Whelchel, A., Wolfe, D., and Lipschultz, F.: Ch. 16: Northeast. Climate Change Impacts in the United States: The Third National Climate Assessment, edited by: Melillo, J. M., Richmond, T. C., and Yohe, G. W., US Global Change Research Program, 16-1-nn, https://doi.org/10.7930/J0SF2T3P, 2014.

Hou, J., D'Andrea, W. J., and Huang, Y.: Can sedimentary leaf waxes record $\mathrm{D} / \mathrm{H}$ ratios of continental precipitation? Field, model, and experimental assessments, Geochim. Cosmochim. Ac., 72, 3503-3517, 2008.

Huang, Y., Shuman, B., Wang, Y., and Webb III, T.: Hydrogen isotope ratios of individual lipids in lake sediments as novel tracers of climatic and environmental change: a surface sediment test, J. Paleolimnol., 31, 363-375, 2004.

Kiser, R. W., Donaldson, J. R., and Olson, P. R.: The Effect of Rotenone on Zooplankton Populations in Freshwater Lakes, T. Am. Fish. Soc., 92, 17-24, 1963. 
Klok, J., Baas, M., Cox, H.C., de Leeuw, J. W., and Schenck, P. A.: Loliolides in dihydroactinidiolide in a recent marine sediment probably indicate a major transformation pathway of carotenoids, Tetrahedron Lett., 25, 5577-5580, 1984.

Kunkel, K. E, Stevens, L. E., Stevens, S. E., Sun, L., Janssen, E., Wuebbles, D., Rennells, J., DeGaetano, A., and Dobson, J. G.: Regional Climate Trends and Scenarios for the U.S. National Climate Assessment. Part 1. Climate of the Northeast U.S., NOAA Technical Report NESDIS 142-1, 79 pp., 2013.

Loomis, S. E., Russell, J. M., Ladd, B., Street-Perrott, F. A., and Sinninghe Damsté, J. S.: Calibration and application of the branched GDGT temperature proxy on East African lake sediments, Earth Planet. Sc. Lett., 357/358, 277-288, 2012.

Loomis, S. E., Russell, J. M., Heureux, A. M., D’Andrea, W. J., and Sinninghe Damsté, J. S.: Seasonal variability of branched glycerol dialkyl glycerol tetraethers (brGDGTs) in a temperate lake system, Geochim. Cosmochim. Ac., 144, 173-187, 2014.

Marlon, J. R., Pederson, N., Nolan, C., Goring, S., Shuman, B., Robertson, A., Booth, R., Bartlein, P. J., Berke, M. A., Clifford, M., Cook, E., Dieffenbacher-Krall, A., Dietze, M. C., Hessl, A., Hubeny, J. B., Jackson, S. T., Marsicek, J., McLachlan, J., Mock, C. J., Moore, D. J. P., Nichols, J., Peteet, D., Schaefer, K., Trouet, V., Umbanhowar, C., Williams, J. W., and Yu, Z.: Climatic history of the northeastern United States during the past 3000 years, Clim. Past, 13, 1355-1379, https://doi.org/10.5194/cp-13-13552017, 2017.

Meyers, S. R.: Seeing red in cyclic stratigraphy: Spectral noise estimation for astrochronology, Paleoceanography, 27, PA3228, https://doi.org/10.1029/2012PA002307, 2012.

Miller, D. R., Castañeda, I. S., Bradley, R. S., and MacDonald, D.: Local and regional wildfire activity in central Maine (USA) during the past 900 years, J. Paleolimnol., 58, 455-466, 2017.

Miller, D. R., Habicht, M. H., Keisling, B. A., Casteñeda, I. S., and Bradley, R. S.: Basin Pond brGDGT Data, NOAA Paleoclimate Data Archives, available at: https://www.ncdc.noaa.gov/ data-access/paleoclimatology-data/datasets, last access: November 2018 .

National Oceanic and Atmospheric Administration (NOAA): National Climatic Data Center, available at: https://www.ncdc.noaa. gov, last access: 17 October 2014.

Nichols, J. E. and Huang, Y.: Hydroclimate of the northeastern United States is highly sensitive to solar forcing, Geophys. Res. Lett., 39, L04707, https://doi.org/10.1029/2011GL050720, 2012.

Oswald, W., Faison, E. K., Foster, D. R., Doughty, E. D., Hall, B. R., and Hansen, B. C. S.: Post-glacial changes in spatial patterns of vegetation across southern New England, J. Biogeogr., 34, 900913, 2007.

O'Sullivan, P. E.: Annually-laminated lake sediments and the study of Quaternary environmental changes - a review, Quaternary Sci. Rev., 1, 245-313, 1983.

PAGES 2k Consortium: Continental-scale temperature variability during the past two millennia, Nat. Geosci., 6, 339-346, 2013.

Pearson, E. J., Juggins, S., Talbot, H. M., Weckström, J., Rosén, P., Ryves, D. B., Roberts, S. J., and Schmidt, R.: A lacustrine GDGT-temperature calibration from the Scandinavian Arctic to Antarctic: Renewed potential for the application of GDGTpaleothermometry in lakes, Geochim. Cosmochim. Ac., 75, 6225-6238, 2011.
Peterse, F., van der Meer, J., Schouten, S., Weijers, J. W. H., Fierer, N., Jackson, R. B., Kim, J.-H., and Sinninghe Damsté, J. S.: Revised calibration of the MBT-CBT paleotemperature proxy based on branched tetraether membrane lipids in surface soils, Geochim. Cosmochim. Ac., 96, 215-229, 2012.

Repeta, D. J.: Carotenoid diagenesis in recent marine sediments: II. Degradation of fucoxanthin to loliolide, Geochim. Cosmochim. Ac., 53, 699-707, 1989.

Russell, J. M., Hopmans, E. C., Loomis, S. E., Liang, J., and Sinninghe Damste, J. S.: Distributions of 5- and 6-methyl branched glycerol dialkyl glycerol tetraethers (brGDGTs) in East African lake sediment: Effects of temperature, $\mathrm{pH}$, and new lacustrine paleotemperature calibrations, Org. Geochem., 117, 56-69, 2018.

Sanni, S. and Wærvågen, S. B.: Oligotrophication as a result of planktivorous fish removal with rotenone in the small, eutrophic, Lake Mosvatn, Norway, Hydrobiologia, 200/201, 263274, 1990.

Schoon, P. L., de Kluijver, A., Middelburg, J. J., Downing, J. A., Sinninghe Damsté, J. S., and Schouten, S.: Influence of lake water $\mathrm{pH}$ and alkalinity on the distribution of core and intact polar branched glycerol dialkyl glycerol tetraethers (GDGTs) in lakes, Org. Geochem., 60, 72-82, 2013.

Schouten, S., Hopmans, E. C., Schefus, E., and Sinninghe Damsté, J. S.: Distributional variations in marine chrenarchaeotal membrane lipids: a new tool for reconstructing ancient sea water temperatures?, Earth Planet. Sc. Lett., 204, 265-274, 2002.

Shuman, B., Huang, Y., Newby, P., and Wang, Y.: Compoundspecific isotopic analyses track changes in the seasonality of precipitation in the Northeastern United States at ca. 8200 cal yr BP, Quaternary Sci. Rev., 25, 2992-3002, 2006.

Sinninghe Damsté, J. S., Hopmans, E. C., Pancost, R. D., Schouten, S., and Geenevasen, J. A. J.: Newly discovered non-isoprenoid glycerol dialkylglycerol tetraether lipids in sediments, Chem. Commun., 17, 1683-1684, 2000.

Sinninghe Damsté, J. S., Ossebaar, J., Abbas, B., Schouten, S., and Verschuren, D.: Fluxes and distribution of tetraether lipids in an equatorial African lake: Constraints on the application of the $\mathrm{TEX}_{86}$ palaeothermometer and BIT index in lacustrine settings, Geochim. Cosmochim. Ac., 73, 4232-4249, 2009.

Sinninghe Damsté, J. S., Rijpstra, W. I. C., Hopmans, E. C., Weijers, J. W. H., Foesel, B. U., Overmann, J., and Dedysh, S. N.: 13,16Dimethyl Octacosanedioic Acid (iso-Diabolic Acid), a Common Membrane-Spanning Lipid of Acidobacteria Subdivisions 1 and 3, Appl. Environ. Microb., 77, 4147-4154, 2011.

Sinninghe Damsté, J. S., Ossebaar, J., Schouten, S., and Verschuren, D.: Distribution of tetraether lipids in the 25 -ka sedimentary record of Lake Challa: extracting reliable $\mathrm{TEX}_{86}$ and $\mathrm{MBT}_{5 \mathrm{ME}}^{\prime} / \mathrm{CBT}$ palaeotemperatures from an equatorial African lake, Quaternary Sci. Rev., 50, 43-54, 2012.

Sinninghe Damsté, J. S., Rijpastra, W. I. C., Foesel, B. U., Huber, K. J., Overmann, J., Nakagawa, S., Kim, J. J., Dunfield, P. F., Dedysh, S. N., and Villanueva, L.: An overview of the occurrence of either- and ester-linked iso-diabolic acid membrane lipids in microbial cultures of the Acidobacteria: Implications for brGDGT paleoproxies for temperature and $\mathrm{pH}$, Org. Geochem., 124, 63-76, 2018.

Sun, Q., Chu, G., Liu, M., Xie, M., Li, S., Ling, Y., Wang, X., Shi, L., Jia, G., and Lü, H.: Distributions and temperature dependence of branched glycerol dialkyl glycerol tetraethers in recent lacus- 
trine sediments from China and Nepal, J. Geophys. Res., 116, 1-12, 2011.

Sun, C., Li, J., and Jin, F.-F.: A delayed oscillator model for the quasi-periodic multidecadal variability of the NAO, Clim. Dynam., 45, 2083-2099, 2015.

Tierney, J. E. and Russell, J. M.: Distributions of branched GDGTs in a tropical lake system: Implications for lacustrine application of the MBT / CBT paleoproxy, Org. Geochem., 40, 1032-1036, 2009.

Tierney, J. E., Russell, J. M., Eggermont, H., Hopmans, E. C., Verschuren, D., and Sinninghe Damsté, J. S.: Environmental controls on branched tetraether lipid distributions in tropical East African lake sediments, Geochim. Cosmochim. Ac., 74, 49024918, 2010.

Tierney, J. E., Schouten, S., Pitcher, A., Hopmans, E. C., and Sinninghe Damsté, J. S.: Core and intact polar glycerol dialkyl glycerol tetraethers (GDGTs) in Sand Pond, Warwick, Rhode Island (USA): Insights into the origin of lacustrine GDGTs, Geochim. Cosmochim. Ac., 77, 561-581, 2012.

Trenberth, K., Zhang, R., and National Center for Atmospheric Research Staff (Eds): The Climate Data Guide: Atlantic Multidecadal Oscillation (AMO), 2017.

Tyler, J., Jones, V., Nederbragt, A. J., and Thurow, J. W.: Assessing past temperature and soil $\mathrm{pH}$ estimates from bacterial tetraether membrane lipids: Evidence from the recent lake sediments of Lochnagar, Scotland, J. Geophys. Res.-Atmos., 115, G01015, https://doi.org/10.1029/2009JG001109, 2010.

United States Geological Survey (USGS) Basin Pond: ME Survey and Overview: https://www.climate-of-the-past.net/Copernicus_ Publications_Reference_Types.pdf (last access: 17 September 2014), 1996

Volkman, J. K., Barrett, S. M., Blackburn, S. I., Mansour, M. P., Sikes, E. L., and Gelin, F.: Microalgal biomarkers: A review of recent research developments, Org. Geochem., 29, 1163-1179, 1998.

Volkman, J.: Sterols in microorganisms, Appl. Microbiol. Biotechnol., 60, 495-506, 2003.
Wang, H., Liu, W., Zhang, C. L., Wang, Z., Wang, J., Liu, Z., and Dong, H.: Distribution of glycerol dialkyl glycerol tetraethers in surface sediments of Lake Qinghai and surrounding soil, Org. Geochem., 47, 78-87, 2012.

Webb, T., Shuman, B., Leduc, P., Newby, P., and Miller, N.: Late Quaternary climate history of western New York State, Bulletin of the Buffalo Society of Natural Sciences, 37, 11-13, 2003.

Weber, Y., De Jonge, C., Rijpstra, W. I. C., Hopmans, E. C., Stadnitskaia, A., Schubert, C. J., Lehmann, M. F., Sinninghe Damsté, J. S., and Niemann, H.: Identification and carbon isotope composition of a novel branched GDGT isomer in lake sediments: Evidence for lacustrine branched GDGT production, Geochim. Cosmochim. Ac., 154, 118-129, 2015.

Weijers, J. W. H., Schouten, S., van den Donker, J. C., Hopmans, E. C., and Sinninghe Damsté, J. S.: Environmental controls on bacterial tetraether membrane lipid distribution in soils, Geochim. Cosmochim. Ac., 71, 703-713, 2007.

Wetzel, A.: Biogenic structures in modern slope to deep-sea sediments in the Sulu Sea Basin (Philippines), Palaeogeogr. Palaeocl., 42, 285-304, 1983.

Zell, C., Kim, J.-H., Moreira-Turcq, P., Abril, G., Hopmans, E. C., Bonnet, M.-P., Sobrinho, R. L., and Sinninghe Damsté, J. S.: Disentangling the origins of branched tetraether lipids and crenarchaeol in the lower Amazon River: Implications for GDGT-based proxies, Limnol. Oceanogr., 58, 343-353, 2013.

Zhang, Z., Smittenberg, R. H., and Bradley, R. S.: GDGT distribution in a stratified lake and implications for the application of $\mathrm{TEX}_{86}$ in paleoenvironmental reconstructions, Sci. Rep., 6, 34465, https://doi.org/10.1038/srep34465, 2016.

Zhu, C., Weijers, J. W. H., Wagner, T., Pan, J.-M., Chen, J.-F., and Pancost, R. D.: Sources and distributions of tetraether lipids in surface sediments across a large river-dominated continental margin, Org. Geochem., 42, 376-386, 2011.

Zink, K.-G., Vandergoes, M. J., Mangelsdorf, K., DieffenbacherKrall, A. C., and Schwark, L.: Application of bacterial glycerol dialkyl glycerol tetraethers (GDGTs) to develop modern and past temperature estimates from New Zealand lakes, Organic Geochemistry, Advances in Organic Geochemistry 2009, Proceedings of the 24th International Meeting on Organic Geochemistry, Org. Geochem., 41, 1060-1066, 2010. 